\title{
Labour party pledges to end privatization of UK laboratories
}

London. Britain's opposition Labour party promised this week that if - as widely tipped - it wins next year's general election, it will halt the programme launched by the Conservative government under which all government laboratories are being systematically evaluated as potential candidates for privatization.

The programme, known as the Prior Options Review, has already led to responsibility for a number of government laboratories being passed to private-sector organizations under a variety of arrangements, ranging from direct sell-offs to the contracting-out of managerial responsibility. Included in the current review are many laboratories belonging to the six research councils.

But such moves have been highly controversial among those - including the labour unions representing the scientists and technicians working in such institutions who believe the government should maintain central responsibility for them.

In a policy statement on industrial strategy issued this week, the Labour party describes the laboratories as a "vital national resource and a source of crucial research expertise". It adds that they also have "a vital role to play in offering independent, impartial advice to government".

The document, which was launched by Adam Ingram, the party's shadow minister for science and technology, during the annual meeting of the British Association for the Advancement of Science, promises that a future Labour government will take steps to increase the involvement of women in science. It will also try to "strengthen and rationalize the current UK intellectual property rights system" - although no details are given of how this might be done.

But there is no indication that the Labour party is prepared to commit itself to providing extra funds to support research, either in universities or industry. And the party says that, even though it sympathizes with scientists who were "dismayed" at last year's decision to move the Office of Science and Technology into the Department of Trade and Industry, with no prior consultation, it has no plans to reverse the move.

"Another process of rapid change would not necessarily be in the best interests of the scientific community," says the document, which sets out the party's general approach to the area of innovation, design, science and technology. It merely promises that a Labour government would "undertake a thorough review of the effectiveness of the new structure, in consultation with industry and the research and academic sectors".

\section{ESA members reluctant to replace Cluster mission}

Munich. Prospects are looking bleak for rebuilding and relaunching the Cluster mission of the European Space Agency (ESA), whose four satellites were lost when Ariane-5 exploded during its first test flight earlier this summer. A search for financing from European governments has so far drawn a blank.

Nevertheless, scientists involved in the mission reaffirmed their determination last week, at a meeting of ESA's Solar System working group in Paris, to continue the fight for a full recovery plan. "We're not going to give up the battle before it has begun," says André Balogh of Imperial College, London.

Cluster was intended to study the electrical and magnetic field environment of the Earth. It was scientifically unique, as its four-satellite configuration would have allowed the first three-dimensional analysis of this environment.

After the accident, ESA drew up a proposed rescue plan that suggested launching Cluster's single spare satellite, called Phoenix, on the next Ariane-5 test launch early next year. ESA suggested that this could be joined three years later either by three further identical satellites, or by three minisatellites, to allow multipoint measurements (see Nature 382, 102; 1996).

Like the first test launch, this would have been free. But this idea has now been abandoned by ESA's science directorate, headed by Roger Bonnet, because of fears that the problems that led to the first failure may not be rectified in time.

Tempers in ESA have become severely frayed over the issue. Jean-Marie Luton, ESA's director general, is reported to be unhappy that such criticisms have reached the public arena, and is making no public comment on the Cluster affair.

The science directorate, in turn, is unhappy that it will not be offered a discount to fly Phoenix on the first commercial launch of Ariane-5, due at the end of next year. The full price is around ECU130 million (US\$165 million). Bonnet, with the support of the scientific community, is trying to achieve a compromise from Luton and ESA's launcher division.

The two teams set up to cost the additional satellite options learned last week that prospects for financing are not good. So far no money has been found within ESA to finance the full-sized units, and member states - which, it was hoped, would pay for the minisatellites - have not indicated a willingness to foot the bill.

But discussions are continuing, and these options will remain open until the Science Policy Committee, ESA's decision-making body comprising representatives of member states, meets again at the end of November. Meanwhile ESA is negotiating with industry to try to reduce costings for either option.

It has been an unhappy summer for solar scientists. A Russian-led mission, Interbal, which shares some of Cluster's scientific aims, suffered a major setback last week when the power system of the smaller of its two satellites failed after launch. As a result, scientists will lose the opportunity offered by the mission of measuring the magnetosphere contemporaneously at two points.

Meanwhile, the scientists involved in Cluster are demanding some financial compensation from ESA for the Ariane accident, perhaps in the form of a free or discounted launch, along the lines being discussed. They are angered by the conclusion of the independent board of inquiry that management negligence contributed to the software failure which sent the rocket off course and required it to be destroyed (see Nature 382, 386; 1996).

Alison Abbott

\section{Nuclear treaty text set for UN approval}

Paris. Australia led an attempt this week to have the current text of the Comprehensive Test Ban Treaty (CTBT) sponsored as a resolution to the UN General Assembly. As 121 of the 185 UN countries have agreed to co-sponsor the resolution, it is virtually assured the two-thirds majority it needs to pass.

The co-sponsors include the five nuclear weapons states: the United States, Russia, China, France and the United Kingdom. Of the three threshold weapons states, Israel is sponsoring the Australian resolution, while Pakistan is said to be likely to do so. India, which last month vetoed the adoption of the text by the usual route - consensus at the Conference on Disarmament in Geneva - still refuses to sign, complaining that the text provides insufficient commitment to nuclear disarmament.

Countries that co-sponsor the text agree not only to support the treaty but also to oppose any amendments and to seek further co-sponsors. This means that the 121 co-sponsors are already more than enough to block amendments, given that these require a twothirds majority to pass. Supporters of the text fear that any amendments could upset hard-won consensus on other contentious issues. 